\title{
Impacts of Education's Intervention on Solid Medical Waste Management in Improving Knowledge, Attitude, and Behavior of Medical Health Workers
}

\author{
Sofia Sofia ${ }^{1 *}$, Wiku S T Yogasmara ${ }^{2}$, Hafni Andayani ${ }^{3}$, Ratna Idayati $^{4}$ \\ ${ }^{1}$ Postgraduate Program in Public Health, Faculty of Medicine, Universitas Syiah Kuala, Banda Aceh, \\ Indonesia \\ Research Center for Environmental and Natural Resources, Universitas Syiah Kuala, Banda Aceh, \\ Indonesia \\ ${ }^{2}$ Faculty of Medicine, Universitas Syiah Kuala, Banda Aceh, Indonesia \\ ${ }^{3}$ Department of Public Health, Faculty of Medicine, Universitas Syiah Kuala, Banda Aceh, Indonesia \\ 4Department of HB Physiology, Faculty of Medicine, Universitas Syiah Kuala, Banda Aceh, Indonesia \\ Email:sofia@unsyiah.ac.id
}

\begin{abstract}
:
The purpose of this study was to determine the effect of providing education on increasing knowledge, attitudes, and behavior of medical officers in solid medical waste management at the Regional General Hospital dr. Zainoel Abidin Banda Aceh, Indonesia. The research design used was a quasi experiment with the Wilcoxon comparison test. The research sample was the medical officer of dr. Zainoel Abidin Banda Aceh as many as 94 people who were divided into treatment and control groups. Knowledge, attitude, and the behavior of medical personnel was measured by interview using a questionnaire. The results showed that there was an effect of educational interventions on increasing the knowledge, attitudes, and behavior of medical personnel in the management of medical solid waste in the treatment and control groups ( $p$ $<0.05)$. The results of the Wilcoxon test between the treatment groups on knowledge, attitudes, and behavior before and after the educational intervention showed a significant difference ( $p=$ $0.000)$, whereas in the control group between before and after the educational intervention did not show a difference with the $p$-value of knowledge ( $p=0.102)$; attitude and behavior ( $p=$ 0.157). In the control group, the level of knowledge, attitudes and behavior tends to remain at a sufficient level. The conclusion of this study shows that educational interventions can provide an increase in the knowledge, attitudes and behavior of medical personnel in implementing solid medical waste management at dr. Zainoel Abidin Banda Aceh.
\end{abstract}

Keywords:

solid medical waste management; medical officer; knowledge; attitude; behavior

\section{Introduction}

The hospital is a health service unit that produces medical waste. The medical waste produced is in the form of liquid medical waste and solid medical waste. According to the World Health Organization (WHO) around $10-25 \%$ of this waste is categorized as dangerous and can affect public health and pollute the environment. In particular, the medical waste generated from this hospital if not handled properly and correctly can cause health problems for health workers working in the hospital, for patients, and for the community. ${ }^{(1)}$ Solid medical waste generated from hospital activities such as syringes, bandages, intravenous drip bottles, blood bags, biomedical waste such as body organs, pressurized container waste, waste with high heavy metal contentand waste body tissue ${ }^{(3,4-6)}$. The treatment of this waste starts from the handling, management and disposal stages if it is not carried out properly, it will cause adverse health and environmental impacts ${ }^{(7)}$. This medical waste management has 

complex problems. This waste needs to be managed in accordance with the existing rules and human resources who understand the problems in medical waste management properly are also needed in order to achieve good performance. ${ }^{(7)}$

Based on a survey conducted by the World Health Organization (WHO) in 24 developing countries, it shows that $58 \%$ of health care centers have not met the criteria for health care facilities that have used appropriate waste disposal methods. ${ }^{(8)}$ Those things related to the too much result of solid waste, liquid gases and air emission (Mardiana, 2020). In Indonesia, the average amount of health care waste generated is $0.8 \mathrm{~kg}-6.0 \mathrm{~kg} /$ person / year, while the hazardous health service waste is $0.3 \mathrm{~kg}-0.4 \mathrm{~kg} /$ person / year. ${ }^{(7)} \mathrm{A}$ survey conducted in Pakistan at 12 hospitals found that $73.85 \%$ of medical waste produced was solid medical waste, $25.8 \%$ of hazardous infectious waste, and $0.87 \%$ sharp object waste. This solid medical waste consists of $15.76 \%$ paper, $13.41 \%$ plastics, $21.77 \%$ textiles, $6.47 \%$ glass, $1.99 \%$ rubber, $0.44 \%$ metal and $40.17 \%$ others. . There were also findings that the sorting, storage and transportation process of medical waste was still poor. ${ }^{(9)}$ Another survey also found that from government hospitals and private hospitals the average total weight of waste produced was $1.53 \mathrm{~kg} /$ patient / days which consists of $75.15 \%$ are solid medical waste and the rest is biomedical waste. ${ }^{(10)}$

At the Regional General Hospital (RSUD)dr. Zainoel Abidin, Banda Aceh, Indonesia, the medical waste produced is around $250 \mathrm{~kg}-300 \mathrm{~kg}$ per day and medical waste management is carried out independently by the Sanitation and Environmental Maintenance Installation (IPSL). This data shows the large production of medical waste in dr. Zainoel Abidin Banda Aceh, so it is necessary to carry out a good waste management process so as not to cause dangerous impacts

The management of medical waste is strongly influenced by human resources, especially medical waste processing officers who have a strong knowledge base, a good attitude towards waste management, and appropriate behavior in the waste management process. The role of medical officers as processors of medical waste is one of the components in the success of medical waste management in dr. Zainoel Abidin Banda is important in medical waste management. ${ }^{(11)}$

The importance of knowledge, attitudes, and behavior inMedical waste management also affects the environment because if medical personnel do not carry out proper and proper waste management it will cause environmental damage in the form of medical waste pollution and become an impact factor that can endanger health. ${ }^{(10)}$ This incident can generally occur due to a lack of knowledge or facilities in waste management at the facility, especially in hospitals. $^{(7)}$

This study aims to conduct research on the effect of providing education on the knowledge, attitudes and behavior of medical personnel in medical waste management at dr. Zainoel Abidin Banda Aceh. 


\section{Research Methods}

This study uses a quasi-experimental design,pretest-posttest control groupdesignby involving the control group and the treatment group to assess the level of knowledge, attitudes and behavior. In the treatment group, additional information was given through booklets regarding solid medical waste treatment, while the control group was not given any intervention. This research was conducted at the Regional General Hospital dr. Zainoel Abidin Banda Aceh, Indonesia. The waste material or tailings may be disposed of in a number of ways (Gebru, 2019).

The sample is medical personnel who are directly involved in the solid medical waste management process which is determined by total sampling with a total of 94 people. The sample must meet the inclusion criteria, namely as a medical officer who is still actively working at Zainoel Abidin Hospital, Banda Aceh, Indonesia. The research sample was divided into 2 groups, namely 47 people as the control group and 47 people as the treatment group. Sampling as group members was done randomly with the simple random sampling method. The treatment group will be given a booklet as a source of education regarding the processing and management of solid medical waste. The control group was not given any intervention and only acted as a comparison to the treatment group.

Measuring the level of knowledge, attitudes and behavior is carried out through interviews using a questionnaire. The questionnaire contains questions regarding the knowledge of medical staff about processing and management techniques for solid medical waste, attitudes of medical staff towards solid medical waste management, and behavior of medical personnel in processing and managing solid medical waste. Measurements were taken 2 times as a pretest and posttest. Intervention was carried out 3-5 days after the pretest and behavioral observations were also made of medical personnel who were carrying out their activities. The validity test of the questionnaire has been carried out and the results are obtained with a validity value $>0.514$ and a reliability test of $0.860-0.897$ which indicates that this questionnaire is valid and reliable.

Data analysis was performed using the Wilcoxon Signed Rank Test. The $\alpha$ value used is $<0.05$ as a conclusion that the hypothesis is accepted. Research ethics was carried out with certificate number 61 / KE / FK / 2017 from the Ethical Feasibility Committee of the Faculty of Medicine, Syiah Kuala University.

\section{Results and Discussion}

\subsection{Results}

Most of the results of the measurement of the respondent's level of knowledge between the treatment group (P1) were $31(66.0 \%)$ and the control group (P0) was $34(72.3 \%)$ before being given the knowledge intervention at a sufficient level as presented in table 1 . 
Table 1. Level of Knowledge Regarding Solid Medical Waste Management Prior to Intervention

\begin{tabular}{|l|l|c|c|c|c|}
\hline \multirow{2}{*}{ No. } & \multirow{2}{*}{ Knowledge level } & \multicolumn{2}{|c|}{ Treatment Group (P1) } & \multicolumn{2}{c|}{ Control Group (P0) } \\
\cline { 3 - 6 } & & $\mathbf{N}$ & $\mathbf{0}$ & $\mathbf{N}$ & $\mathbf{\%}$ \\
\hline 1 & Not good & 1 & 2.1 & 1 & 2.1 \\
\hline 2 & Enough & 31 & 66.0 & 34 & 72.3 \\
\hline 3 & Good & 15 & 31.9 & 12 & 25.5 \\
\hline \multicolumn{2}{|l}{ TOTAL } & $\mathbf{4 7}$ & $\mathbf{1 0 0}$ & $\mathbf{4 7}$ & $\mathbf{1 0 0}$ \\
\hline
\end{tabular}

In general, polymer composite materials are molded in solid form and avoid the occurrence of gas bubbles trapped in the matrix (Zulfikar, 2020). Meanwhile, after being given the knowledge intervention, it was found that the change in the level of knowledge of respondents in the treatment group (P1) increased to be good $43(91.5 \%)$ while the control group (P0) remained mostly at a sufficient level of knowledge $30(63.8 \%)$ such as shown in Table 2.

Table 2. Level of Knowledge Regarding Solid Medical Waste Management after Intervention

\begin{tabular}{|l|l|c|c|c|c|}
\hline \multirow{2}{*}{ No. } & \multirow{2}{*}{ Knowledge level } & \multicolumn{2}{|c|}{ Treatment Group (P1) } & \multicolumn{2}{c|}{ Control Group (P0) } \\
\cline { 3 - 6 } & & $\mathbf{n}$ & $\mathbf{\%}$ & $\mathbf{N}$ & $\mathbf{0}$ \\
\hline 1 & Not good & 0 & 0 & 1 & 2.1 \\
\hline 2 & Enough & 4 & 8.5 & 30 & 63.8 \\
\hline 3 & Good & 43 & 91.5 & 16 & 34.0 \\
\hline \multicolumn{2}{|l}{ TOTAL } & $\mathbf{4 7}$ & $\mathbf{1 0 0}$ & $\mathbf{4 7}$ & $\mathbf{1 0 0}$ \\
\hline
\end{tabular}

The results of the Wicoxon Signed Rank Test showed that the overall knowledge of the respondents after getting the knowledge intervention had an increase with a significance value of 0.000 , while the control group had no effect with a significance level of 0.102 . Based on this value, the intervention of knowledge about solid medical waste management for health workers has an effect on changes in the level of knowledge.

The results of measuring the respondent's attitude before being given intervention in the treatment group (P1) showed almost the same level between the moderate category (20 $(42.6 \%))$ and the good category $((27(57.4 \%))$ while in the control group (P0) before the intervention was given, it was in the sufficient category of $33(70.2 \%)$ as shown in table 3 .

Table 3. Attitudes Regarding Solid Medical Waste Management Prior to Intervention

\begin{tabular}{|l|l|c|c|c|c|}
\hline \multirow{2}{*}{ No. } & \multirow{2}{*}{ Attitude } & \multicolumn{2}{|c|}{ Treatment Group (P1) } & \multicolumn{2}{c|}{ Control Group (P0) } \\
\cline { 3 - 6 } & & $\mathbf{n}$ & $\mathbf{0}$ & $\mathbf{N}$ & $\mathbf{\%}$ \\
\hline 1 & Enough & 20 & 42.6 & 33 & 70.2 \\
\hline
\end{tabular}




\begin{tabular}{|l|l|c|c|c|c|}
\hline 2 & Good & 27 & 57.4 & 14 & 29.8 \\
\hline TOTAL & $\mathbf{4 7}$ & $\mathbf{1 0 0}$ & $\mathbf{4 7}$ & $\mathbf{1 0 0}$ \\
\hline
\end{tabular}

Whereas the attitude of the respondents after being given intervention in the treatment group (P1) showed a large increase turned into almost entirely at a good level of 46 (97.9\%) while the control group remained at a sufficient level of $31(66.0 \%)$ as shown in table 4.

Table 4. Attitudes Regarding Solid Medical Waste Management after Intervention

\begin{tabular}{|l|l|c|c|c|c|}
\hline \multirow{2}{*}{ No. } & \multirow{2}{*}{ Attitude } & \multicolumn{2}{|c|}{ Treatment Group (P1) } & \multicolumn{2}{c|}{ Control Group (P0) } \\
\cline { 3 - 6 } & & $\mathbf{N}$ & $\mathbf{0}$ & $\mathbf{N}$ & $\mathbf{0}$ \\
\hline 1 & Enough & 1 & 2.1 & 31 & 66.0 \\
\hline 2 & Good & 46 & 97.9 & 16 & 34.0 \\
\hline \multicolumn{2}{|l}{ TOTAL } & $\mathbf{4 7}$ & $\mathbf{1 0 0}$ & $\mathbf{4 7}$ & $\mathbf{1 0 0}$ \\
\hline
\end{tabular}

The results of the Wicoxon Signed Rank Test showed that the overall attitude of the respondents was found to have increased with a significance value of 0.000 , while the control group had no influence with a significance level of 0.157 . Based on this value, the intervention of knowledge about solid medical waste management for health workers has an influence on changes in the level of respondent's attitude.

For the behavioral aspect, the measurement results before being given intervention in the treatment group (P1) were almost the same between sufficient $(24(51.1 \%))$ and good ((22 $(46.8 \%))$ while in the control group (P0) most of the respondents have behavior at a sufficient level of $31(66.0 \%)$ as can be seen in table 5 .

Table 5. Behavior Regarding Solid Medical Waste Management Prior to Intervention

\begin{tabular}{|l|l|c|c|c|c|}
\hline \multirow{2}{*}{ No. } & \multirow{2}{*}{ Behavior } & \multicolumn{2}{|c|}{ Treatment Group (P1) } & \multicolumn{2}{c|}{ Control Group (P0) } \\
\cline { 3 - 6 } & & $\mathbf{n}$ & $\mathbf{0}$ & $\mathbf{n}$ & $\mathbf{\%}$ \\
\hline 1 & Less & 1 & 2.1 & 1 & 2.1 \\
\hline 2 & Enough & 24 & 51.1 & 31 & 66.0 \\
\hline 3 & Good & 22 & 46.8 & 15 & 31.9 \\
\hline \multicolumn{2}{|c|}{ TOTAL } & $\mathbf{4 7}$ & $\mathbf{1 0 0}$ & $\mathbf{4 7}$ & $\mathbf{1 0 0}$ \\
\hline
\end{tabular}

Based on the data from table 4.5, it can be seen that the behavior of medical workers is in the sufficient category. These results are the same as those found in the study of Kumar et al. in Pakistan and in Nigeria. This occurs from the behavior of medical personnel who do not comply with standard procedures established in the hospital. Based on information obtained through interviews with medical officers, it was found that there were not many human resources who handled this medical waste problem and were not skilled in medical waste management plus non-compliance with the prescribed procedures. ${ }^{(12)}$ 
Meanwhile, after the intervention was carried out, changes in the behavior of respondents in the treatment group (P1) mostly changed to be better (45 (95.7\%)) and in the control group (P0) there were still more respondents with sufficient behavior (31 (66.0)\%). This is shown in table 6 .

Table 6. Behavior Regarding Solid Medical Waste Management after Intervention

\begin{tabular}{|l|l|c|c|c|c|}
\hline \multirow{2}{*}{ No. } & \multirow{2}{*}{ Behavior } & \multicolumn{2}{c|}{ Treatment Group (P1) } & \multicolumn{2}{c|}{ Control Group (P0) } \\
\cline { 3 - 6 } & & $\mathbf{n}$ & $\mathbf{0}$ & $\mathbf{N}$ & $\mathbf{0}$ \\
\hline 1 & Less & 1 & 2.1 & 0 & 0 \\
\hline 2 & Enough & 1 & 2.1 & 31 & 66.0 \\
\hline 3 & Good & 45 & 95.7 & 16 & 34.0 \\
\hline \multicolumn{2}{|l|}{ TOTAL } & $\mathbf{4 7}$ & $\mathbf{1 0 0}$ & $\mathbf{4 7}$ & $\mathbf{1 0 0}$ \\
\hline
\end{tabular}

The results of the Wicoxon Signed Rank Test showed that the overall behavior of the respondents was found to have increased with a significance value of 0.000 , while the control group had no influence with a significance level of 0.157 . Based on this value, the intervention of knowledge about solid medical waste management for health workers has an influence on changes in the level of respondent behavior.

\subsection{Discussion}

The management of medical waste handled by health workers in hospitals is very dependent on the understanding of health workers in carrying out their work correctly and appropriately. The knowledge, attitudes and behavior of health workers in managing solid medical waste in hospitals are obtained by each individual through various processes and this is a key factor in carrying out solid medical waste management. In this case, health workers as hospital waste processors are expected to master good medical waste management based on good knowledge, attitudes and behavior as the basis for the actions taken. ${ }^{(12)}$

Research conducted in Egypt on the knowledge and behavior of health workers in hospitals in waste management showed that before the intervention of knowledge, $58 \%$ of respondents from the previous respondent group, the treatment group had moderate knowledge and $25 \%$ and $17 \%$ had bad and good knowledge. This was explained possibly due to the lack of knowledge about medical waste management in the curriculum at the time of education, lack of training, and lack of hands-out and tools in the hospital where they worked (12). The impact of bad knowledge, attitudes and behavior makes solid medical waste management not in accordance with established regulations, so that there will be a decrease in the quality of medical waste management. ${ }^{(11)}$ Medical waste management relies on aspects of knowledge and attitude as a source of knowledge and individual awareness that will be channeled through behavior in the solid medical waste management process. Poor knowledge, attitudes and behavior will also increase the risk of disease transmission and work accidents, because solid medical waste has infectious properties and is dangerous for humans and the environment. ${ }^{(13)}$ 
This study is consistent with Letho et.al, who found that respondents who already knew about the color coding of waste types were important because respondents became aware of how to distinguish between hazardous and harmless infectious wastes, thus helping in sorting waste. ${ }^{(14)}$

Providing knowledge interventions to health workers who carry out solid medical waste treatment provides a change for the better as the results obtained from this study. Intervention of knowledge regarding solid medical waste management on the level of knowledge, attitudes and behavior of health workers who undergo solid medical waste treatment has a significant effect $(p<0.05)$ of this study. This result is in accordance with what was done by Elnor and colleagues who also found that there was a change after the intervention through handouts on the knowledge and behavior of health workers in carrying out medical waste treatment ${ }^{(12)}$. Kumar and friends stated that one of the ways to increase knowledge, attitudes and behavior of medical personnel is by means of training or providing educational interventions. Providing education is proven to significantly increase knowledge, attitudes and behavior ${ }^{(13)}$ good knowledge of solid medical waste handling procedures is very important so that the workplace and environment are healthy, especially for the health of hospital staff, so that training is specifically needed in this regard. ${ }^{(1)}$

The results of this study indicate that health workers do not carry out the collection, sorting and disposal of solid medical waste properly and correctly. This is in line with the results of the study by Anozie et al. which also found that many health workers do not practice proper and proper behavior in disposing of medical waste. Disposal of solid medical waste is carried out in the open and not incinerator for hazardous medical materials is not carried out. Meanwhile, from the hospital a standard procedure has been established regarding the treatment of hazardous solid waste, namely by burning it using an incinerator. ${ }^{(1)}$ Providing information on waste sources, waste categories, quantity, and quality of waste is an important thing in determining effective medical waste management. ${ }^{(15)}$ Ozder et al stated that medical waste management is greatly influenced by the quality of human resources who carry out this task. Officers need a strong knowledge base, good attitude and appropriate behavior towards medical waste management, so that the factors of knowledge, attitude and behavior are important factors that medical personnel must have well ${ }^{(11)}$ Another study conducted at 7 hospitals in Lagos, Nigeria shows that medical staff on duty at the hospital who have good knowledge in carrying out the medical waste management process because they have received training in the hospital where they work and outside the hospital as well as capacity building which is carried out regularly by hospital management .

\section{Conclusion}

The knowledge of health workers about solid medical waste management after intervention in the treatment group showed changes to be good by 43 respondents $(91.5 \%)$. The attitude of health workers about solid medical waste management after intervention in the treatment group had a good attitude as many as 46 respondents $(97.9 \%)$. The behavior of health workers regarding solid medical waste management after intervention in the treatment group had good behavior as many as 45 respondents (95.7\%). The knowledge of health workers about solid medical waste management after intervention in the control group tended to remain, 
namely having sufficient knowledge of 30 respondents $(63.8 \%)$. The attitude of health workers regarding solid medical waste management after intervention in the control group tended to remain constant, namely as many as 31 respondents $(66.0 \%)$. The behavior of health workers regarding solid medical waste management after intervention in the control group tended to be constant, namely as many as 31 respondents $(66.0 \%)$. The comparative test shows that there is a significant effect after being given the intervention of knowledge about solid medical waste management on the knowledge, attitudes and behavior of health workers in the hospital.

\section{References}

Ali, M., Wang, W., Chaudhry, N., Geng, Y., Ashraf, U. (2017).Assessing knowledge, performance, and efficiency for hospital waste management- a comparison of government and private hospitals in Pakistan. Environ Monit Assess. Vol 189(4):181.

Ali, M., Wang, W., Chaudhry, N. (2016). Management of Wastes from Hospitals: A Case Study in Pakistan. Waste Manag Res. Vol 34(1):87-90.

Anozie, O.B, Lawani, L.O, Eze, J.N, Mamah, E.J, Onoh, R.C, Ogah, E.O, Umezurike, D.A, Anozie, R.O. 2017. Knowledge, Attitude and Practice of Healthcare Managers to Medical Waste Management and Occupational Safety Practices: Findings from Southeast Nigeria. Journal of Clinical and Diagnostic Research. Vol-11(3): IC01-IC04.

Awodele, O., Adewoye, A.A., Oparah, A.C. (2016). Assessment of Medical Waste Management in Seven Hospitals in Lagos, Nigeria. BMC Public Health. 16:269.

Chandra B. Pengantar Kesehatan Lingkungan. Jakarta: EGC; 2007.

Departemen Kesehatan RI. Kepmenkes RI No 1204/Menkes/SK/X/2004 tentang Persyaratan Kesehatan Lingkungan Rumah Sakit. 2004.

Departemen Kesehatan RI. Pedoman Penyelenggaraan Kesehatan Lingkungan Puskesmas. Indonesia: Departemen Kesehatan RI; 2006.

Elnour AM, Mohamed M, Moussa R, El-borgy MD, Mohammed A, Elkhalifa E. Impacts of health education on knowledge and practice of hospital staff with regard to Healthcare waste management at White Nile State main hospitals, Sudan. Int J Heal Sci Qassim Univ. 2015;9(3):315-31.

Gebru, M.G. (2019). Phytoremediationof Heavy Metals Released from Mining Waste Drainage Using Selected Plant Species, in Ethiopia. Budapest International Research in Exact Sciences (BirEx) Journal Vol 1 (3): 1-4.

Karawad, L., Elwahaishi, S., Elhamrouh, A., Altabet, A. 2019. Assessment of Medical Solid Waste Management in Misrata Healthcare Centers and Hospitals. Scientific journal of Faculty of Education, Misurata University-Libya. Vol.1(12):28-45.

Kumar R, Somrongthong R, Shaikh BT. Effectiveness of intensive healthcare waste management training model among health professionals at teaching hospitals of Pakistan: a quasi-experimental study. BMC Health Serv Res [Internet]. 2015;15(1):81. Available from: http://bmchealthservres.biomedcentral.com/articles/10.1186/s12913-015-0758-7.

Letho Z, Yangdon T, Lhamo C, Limbu CB, Yoezer S, Jamtsho T, et al. (2021) Awareness and practice of medical waste management among healthcare providers in National Referral Hospital. PLoS ONE 16(1): e0243817. https://doi.org/ 10.1371/journal.pone.0243817. 
Mardiana, S., et. al. (2020). Model of Sugar Industrial Waste Management Based on Cleaner Production (Case Study: Sei Semayang Plantation and Sugar Mill). Budapest International Research in Exact Sciences (BirEx) Journal Vol 2 (1): 113-118.

Motlatla,M and Maluleke, T.X. (2021). Assessment of knowledge about healthcare risk waste management at a tertiary hospital in the northern cape province, South Africa. In J environ Res Public Health. 18(2):449.

Onoh, R. C., Adeke, A. S., Umeokonkwo, C. D., Ekwedigwe, K. C., Agboeze, J., \& Ogah, E. O. (2019). Knowledge and Practices of Health-Care Waste Management among Health Workers in Lassa Fever Treatment Facility in Southeast Nigeria. Nigerian medical journal : journal of the Nigeria Medical Association, 60(5), 257-261. https://doi.org/10.4103/nmj.NMJ_161_18.

Ozder A, Teker B, Eker H, Altındis S, Kocaakman M, Karabay O. Medical waste management training for healthcare managers - a necessity? J Environ Heal Sci Eng [Internet]. 2013;11(1):20. Available from: http://jehse.biomedcentral.com/articles/10.1186/2052336X-11-20.

Pruss A. Pengolahan Aman Limbah Layanan Kesehatan. 1st ed. Raharjo R, editor. Jakarta: EGC; 2005.

Taghipour H. "On-site or Off-site Treatment of Medical Waste. J enviromental Heal Sci Eng. 2014.

World Health Organization (WHO). Health Care Waste. World Heal Organ [nternet]. 2015; Available from: http://www.who.int/mediacentre/factsheets/fs253/en/

Zulfikar, A.J. (2020). Numerical Analysis of Polymer Foam Composite Material (PFCM) Reinforced by Palm Empty Bunch Fiber (PEBF) at Fracture Point Due to High Strain Impact Load. Budapest International Research in Exact Sciences (BirEx) Journal Vol 2 (1): 86-95. 